\title{
The Humour-Culture Interconnection: Exploring Humour Attributes in Morocco and Britain
}

\author{
Dr. Rachid Elkhayma
}

Laboratory of Language and Society, University Ibn Tofail, Kenitra, Morocco

Received: 18 Sep 2021; Received in revised form: 21 Oct 2021; Accepted: 03 Nov 2021; Available online: 12 Nov 2021

(C)2021 The Author(s). Published by Infogain Publication. This is an open access article under the CC BY license

(https://creativecommons.org/licenses/by/4.0/).

\begin{abstract}
This article highlights and underpins the diametrical relationship between humour and culture. It illustrates how inseparable and closely intertwined they are. Culture is always incorporated in humour, and the latter is constantly influenced by the former. Humour may not be appreciated without understanding its surrounding culture, and we cannot grasp all the existing elements of culture without being aware of its humorous side. And since humour is cultural, foreign language students need to know their own culture and its values in order to avoid projecting it on other ones, and so that they have the ability to identify and spot the differences between their culture and foreign ones, such as that of English. In this context, the article lays out details of various old and modern aspects of humour that are characteristic of English and Moroccan cultures. It is not about a comparison between or an examination of any of the two cultures. It is an illustration and a call to understand the traits and attributes of Moroccan and English cultures in terms of their contact with and handling of humour in the past and in modern times.
\end{abstract}

Keywords-Humour, culture, Moroccan culture, English culture.

\section{INTRODUCTION}

Humour and culture are inextricably intertwined as each one is part of the other. Humour exists in every society, and we all agree on its essence and what it is about, but do we share and understand the same humour? As long as it is very cultural, the answer is not always yes. This is exactly what happened to Mathew Helmke (2007) when he was unable to appreciate Moroccans' jokes, even though he understood the meaning, for he missed key cultural details in them.

Cultures are not the same, and each culture has its own traditions, beliefs, experiences, knowledge that are shared by the same community, which Wenger (1998) called "communities of practice". Such groups share the same language and cultural practices, such as humour, and they are able to crack and understand their provoked humour because it reflects a shared common culture. Therefore, in order to fully master a people's language and be able to get the meaning of their humour, the learner should acquire extensive knowledge of their culture. Otherwise, he / she may end up being a "fluent fool" as indicated by Milton Bennet (1993, p. 16), even if they are highly proficient in that language.

Besides, despite cultural differences, societies around the world often laugh at the same humour instances that are likely to be cross-cultural. In this twenty-first century of globalization and social networking, beliefs, values, traditions and experiences quickly transfer from a region to another, and are prone to be accepted and appreciated by other cultures, making them what has come to be known as "global culture" (Richard Lee, 2005). However, local cultures may still be preserving a great deal of their own characteristics and distinctions. This specificity makes it difficult for foreigners to understand all the existing practices, including humour, unless one is aware of the target culture. This implies that every society has its own culture of humour that has developed over centuries, and which varies from historical festivals such as Morocco's 
sultan of students (Sultan Tulba) to literary and artistic exhibitions manifested by British Shakespearian comedies. In this context, this part explores humour-related aspects, characteristics and experiences in Moroccan and English cultures.

\section{HUMOUR AND CULTURE}

The relationship between culture and humour is inseparable. Cultural norms, beliefs and customs that are shared by a particular community are usually understood by its people. This also applies to their humour, which is often appreciated by the same people unless it is universal, as in the case of laughing at stereotypes about particular peoples or countries. Humour targets different topics (marriage, stereotypes, politics, sex, etc.) that are often meaningful to those who have them in common. This holds that members of a community can exclusively make sense of their jokes unless they are aware of all the cultural elements surrounding the use of those jokes. People may appreciate them, but the way they devise them is culturally specific. In this regard, Matthew Helmke (2007), who was an American teacher of English in the University of Fez, went through this very experience of not being able to laugh at his Moroccan counterparts' jokes and various humour situations due to the absence of sufficient cultural knowledge. So, he decided to embark on a learning journey of Moroccan culture so that he could overcome this cultural comprehension hurdle. As a Westerner, Helmke found greater challenges getting to admire and laugh at the local humour of an Eastern society.

I can argue, then, that humour is different from a culture to another and also from the West to the East. According to T. Jiang et al. (2019), people in the East do not generally have positive attitudes towards humour. When compared to Westerners, Easterners "are less likely to use humour as a coping strategy" (p. 1). This denotes that they do not usually integrate it to deal with awkward circumstances or to cope with stress or difficulties. Conversely, Westerners like Americans, British and Canadians usually consider humour a positive attribute, and are more likely to utilize it in numerous meetings and as a defence mechanism in face-saving situations. This reminds us of the shoe-throwing incident against the former US president G. W. Bush in Iraq, wherein he jokingly reacted to such an embarrassing moment by saying "if you want the facts, it's a size 10 shoe that he threw" (BBC, 2008; as cited in Lu et al., 2019, p. 15). In a similar case, the same thing happened to the Chinese premier Wen Jiabao in a speech at Cambridge University. The Chinese official reacted unhappily by stating that "this despicable behaviour cannot stand in the way of friendship between China and the U.K." (Telegraph, 2009; as cited in Lu et al., 2019, p. 15). These two incidents exhibit the level of the sense of humour the two men possess and the differences reflected by their cultural dissimilarities vis-avis addressing and handling humour and life situations.

Although they are Eastern societies, humour is popular in North Africa and the Middle East. In the preIslamic and early Islamic periods, poetry was the main source of humour that was intended to satirize and mock rival tribes and individuals in the Arabic peninsula. Poets were the spoke-persons of their communities who would engage in poetically verbal battles against other opponents. During Prophet Muhammad's time, those from Quraish in Mecca, who disbelieved him (peace be upon him), took the habit of mocking and ridiculing his teachings and his call for Islam.

In the Islamic era, during the Umayyad and Abbasid Dynasties, new poets and authors emerged, and plenty of literary works were produced in different areas, including humour. Renowned poets like Jarir, al-Farazdaq, Abu Nawwas, Bashar Bin Burd, Ibnu al-Rumi, al-Hamdumi, Ibn Sakra and many others excelled in works of humour and irony, while others like al-Jahid, Badiu Zaman alHamadani and Abu al- ${ }^{\circ}$ Aina shined as prose writers (Mubeen, 2008). The period of the Abbasid reign saw the emergence of a third party of poets who were also talented in fusing mockery with madness. They were referred to as the lunatic poets 'al-Shu'ra al-Majaneen'. Prominent figures of this group were "Abu al' Ibar, Abu Jalāla alMahzzumi renowned for his elegiac poem of his donkey, Abu Hakīma renowned for elegy of his property" (Mubeen, 2008, p. 18).

Meanwhile in North Africa, and due to the scarcity of references about humour among native North Africans (the Berber society) in the pre-Islamic history, the researcher sheds light on the rich repertoire of humour practices among Moroccans during Islam. These Moroccan comic rituals and habits are discussed in depth in the section about humour in Morocco. As for Algeria, Tunisia and Libya, they constituted an extension to the Islamic Caliphate in North Africa from the Umayyad dynasty to the Ottoman Empire.

What has been discussed so far accentuates the unequivocal relationship between humour and its culture. In foreign language classes, such a relationship appears to be quite evident because humour is always loaded with cultural meanings. This connotes that understanding a foreign language does not necessarily imply being amused by its humour; a significant dose of the target culture is definitely a requisite as well. The assumption that if students understand the language they can appreciate 
humour has been claimed by research (Bennet, 1993; Deneire, 1995; Jiang et al., 2019; Lewis, 2006; Lu et al., 2019; Mubeen, 2008 and many others) to be erroneous.

Lack of cultural awareness is not the only reason why students cannot admire humour. In fact, there are other linguistic, pragmatic and sociolinguistic factors that determine humour comprehension. Shively (2013) explained that the interpretation of humour necessitates first the hearer's ability to notice the play frame; that is to recognize through the identification of contextualization cues (intonation, smile voice, voice level, facial expression, and so on) that an utterance is meant to be funny. The second necessity entails, on the one hand, having lexical and grammatical skills and, on the other hand, noticing the incongruity that makes an utterance funny. Shively, therefore, admits that "successful comprehension and production often requires a broad base of linguistic, pragmatic, sociolinguistic, and cultural knowledge" (2013, p. 931). With this in mind, it is advantageous for students and teachers to integrate humour in the teaching and learning practices of their EFL settings for the reason that productive communication demands not only linguistic know-how, but also pragmatic, sociolinguistic and cultural knowledge.

\section{HUMOUR IN ENGLISH CULTURE}

It is necessary to explain, at the outset, the English / British dichotomy. By referring to English or England, the researcher uses the terms British, English, Britain or England interchangeably to stand for the same thing even if a number of facts cited here (about humour and historical or artistic figures and events) do not necessarily originate from England, but also from the countries making up Britain (Northern Ireland, Scotland, Wales).

It is generally held that the English are cold-blooded and way too serious. People around the world actually believe the same way, and it is an ordinary stereotype shared by many. The reason may be that England is notorious around the world for its own dull weather, which foreigners probably see as a mirror to English behaviour. But, how true is this?

The reality is far removed from what it seems to be because the English possess an interestingly high sense of humour (Michalik \& Scnizer, 2017). If we look back at the history of British drama and theatre, we will realize that they have a long humour tradition. No doubt that some of the world's famous playwrights and humorous artists are British, from Shakespeare, Oscar Wilde and Charlie Chaplin, to today's John Cleese and Rowan Atkinson, to name but a few.

It is said that England is "known for its humour as France is known for its food and wine." (Hawkins, as cited in Tebbe, 2008, p. 5). This statement underpins the omnipresence of humour in the British culture, as found actually in every society. The English tend to make jokes almost about anything. Nothing can make them laugh more than a joke about unrelated things at inappropriate situations, and "nothing seems to be a taboo as long as some people laugh about it" (Hawkins, as cited in Tebbe, 2008, p. 5). Even when discussing serious matters, jokes found a place in their conversations.

According to Kate Fox's (2004) 'the importance of not being earnest rule', seriousness is palatable but earnestness is not allowed. This entails that the English do not like to be earnest, solemn or too serious; they prefer to maintain a light and humorous communication, instead. When talking about business for instance, they incorporate humour and expect the other to perceive its value, contrary to other nationalities, such as the Germans, who find it unsuitable to joke around in business negotiations (Lewis, 2006).

The English think that their jokes are "subtle, but with a dark or sarcastic undertone" (Emma, 2009, para. 5). They believe that a lot of uses of humour are a reaction to frustrations and sarcasm, which is a pervasive type that is also popular in English humour. There is a salient idea here which is that the English society appears to be quite reserved, and yet highly humorous.

Interestingly, in a recent study by a group of scientists about what constitutes English humour, Andy Bloxham (2008, para. 6) unveiled that "the British have a desire to keep putting themselves down." Kate Fox (2004) corroborated this particular belief that the majority of their humorous conversations involve, for most of the time, irony and sarcasm along with understatement, selfdeprecation, banter, teasing and mockery. Fox asserts that the key element in British humour is the value it maintains in their culture and society. She states that "the most noticeable and important rule about humour in conversation is its dominance and pervasiveness" (224, p. 61).

English humour, according to Jonathan (2010), comprises two main cornerstones that the English are famous for: understatement and irony. The first one indicates something that is less than the real situation. He clarified it as continually understating the current situation or state of affairs. Fox further elaborated on it this way:

A debilitating and painful chronic illness [that] must be described 'as a bit of nuisance'; a truly horrific experience 'well, not exactly what I would have chosen; a sight of breathtaking beauty is 'quite pretty', 
an outstanding performance or achievement is 'not bad'; an act of abominable cruelty is 'not very friendly', and an unforgivably stupid misjudgment is 'not very clever'; the Antarctic is 'rather cold' and the Sahara a 'bit too hot for my taste' (2004, p. 63).

It appears that understatement is the most prevailing mode in England, contrary to overstatement, which is popular in the United States. Using overstatement with the English can be considered a bad form.

The second one is irony. It is again the core of British humour. It actually embraces several forms, such as understatement and self-deprecation. Hall (2006) set an example of irony wherein the British can make jokes about terrible rainy weather by ironically describing it as lovely. Such humour is usually performed in a way that does not display any emotional involvement, or what Double (2005) called 'deadpan delivery' (as cited in Schwarz, 2010, p. 240), which means that people laugh, but do not show any facial signs.

\subsection{History of English humour}

English humour has been played out in different ways and reflected in plenty of places. It touches upon all social classes, and each class has its own space and reason for fun and laughter. This space ranges from Music Halls and theaters during and after the Elizabethan age to radio, television comedy and other media outlets in today's time.

\subsubsection{Humour in English theater}

\subsubsection{A brief overview}

By looking through the diversity of English literature, we will surely be drawn to the history of English theatre that was part of their humour culture. Based on Milling and Thomson (2004), theaters in the middle ages were different from the ones that appeared later. There was only "church liturgy [that] became transformed into staged events" (p. 22). Churches were used for occasional performances in order to control and manipulate the ideas coming out from them.

In the sixteenth century, according to Milling and Thomson (2004) and Kershaw (2004), there were no exclusive locations devoted to theatre. The shows were staged in fixed places like inns. The first theatre was constructed in 1576, and over the few years that followed, seventeen others were built including the iconic Globe Theatre. Shakespeare was a member of the company that set up that theatre, wherein he wrote some of his celebrated plays like Hamlet.
Theatre thrived during the Restoration period. Following Lublin (2011), decoration was upgraded and actresses became part of the profession. The female body represented an astonishing change for the male audience and a significant step forward in theatre production. Prior to this time, male actors used to embody female roles by wearing make-up and women's clothes. Also, more spectators flocked to theatres, and there was like an undeclared contract on silence between the performers and the audience "who would not take this licence to intrude upon the playing space and fiction too far," (Milling \& Thomson, 2004, p. 168).

According to Kershaw (2004), the eighteenth century theatre turned into a business enterprise. Directors maximized their benefits by constructing bigger theatres in order to attract and meet the expectations of a larger public that was fond of great spectacles. "A single entrepreneur owned the acting and production company, owned the theatre or leased it" (p. 6). David Garrick (1717-1779) played a major role at that time. As an actor and director, he revolutionized the new business along with the technical aspects of theatrical performance, including lighting, sets and costumes. During the Victorian age, as Lublin explains, theatre witnessed new changes. More realism and naturalism was brought to theatre in an attempt to put an end to the emotional exaggeration of the time.

In the twentieth century and beyond, as Kershaw (2004) posited, theatre continued to be at the heart of English culture. It was the source of free and also radical voices, and portrayed the prevalent stories people identified with in post-war time. In 1963, England got its first national theatre, which was literally late given the long-standing history of theatre making in England.

In the twenty first century, what is interesting about English theatre is that it has become a vehicle that spreads challenging ideas and information away from the guided public opinion.

\subsubsection{Famous British playwrights}

In writing about theatre in Britain, we mostly think of a number of prominent figures who have greatly marked British theatre, drama and the humour scene like William Shakespeare, Ben Jonson, Christopher Marlowe, Thomas Kyde, John Fletcher, George Bernard Shaw, T. S. Eliot, Sarah Kane, Alan Bennett, Harold Pinter and others. Their order of appearance can be split into different eras starting from the Elizabethan age. As maintained by Milling and Thomson (2004), the most influential figure of all times is definitely William Shakespeare. He appeared in the sixteenth century, and was one of the few playwrights to have worked on comedies (As You Like It and others), tragedies (Hamlet, Othelo and other masterpieces) and 
histories (Henry V, Henry VIII, etc.). He is seen as one of the greatest playwrights in English literature and culture.

Shakespeare's contribution to English humour and theatre is remarkable. His plays were the first to attract huge masses from all walks of life. His theatre was also the one that was filled with audiences emotionally glued to the stage, to the extent that many would even engage in stage events (Milling and Thomson, 2004). Besides, Shakespeare was not only a successful writer of enormously appealing plays, but an actor and a performer in them, too.

Along with Shakespeare, many other renowned playwrights were highly acclaimed in British literature during and after the reign of Queen Elizabeth $1^{\text {st }}$. As mentioned in Hopkins (2008), one prominent figure is by no means Christopher Marlowe. He is both a playwright and a translator, and a major dramatist of the Elizabethan age. Marlowe was an exact contemporary of Shakespeare, but was not influenced by Shakespearean drama. Some say he was "a much quicker starter than Shakespeare" (Hopkins, 2008, p. 56). Marlowe is famous for his remarkable contribution to theatre with masterpieces like The Jew of Malta, Tamburlaine the Great, The Tragical History of Doctor Faustus and so on (Hopkins, 2008).

Another figure of the seventeenth century is Ben Johnson. According to Bloom (2004), he was Shakespeare's rival and emulator, and is one of the most significant playwrights of the English Renaissance. Jonson's theatrical work is very considerable. He wrote, among other genres, numerous plays like Every Man in His Humour, Volpone, a Tale of a Tub (Bloom, 2004). In addition, Ben Jonson is seen as the first to have invented and popularized the comedy of humours, and he was the one to have invented "satirical drama - a new kind of drama that he conceived of as an assault on existing theatrical conventions" (Bloom, 2004, p. 247).

Moving to the nineteenth century, particularly during the Victorian period, we come across a distinguished British-Irish playwright (George Bernard Shaw) whose contribution to theatre and humour is outstanding. As held by Kershaw (2004), he is considered to be the most renowned playwright after William Shakespeare. Kershaw describes him as a "skilled in music and its analysis, a critic of sensitive and wide-ranging proportions, a master prose stylist, a political thinker and activist of prodigious and steady energies, the greatest playwright of the Edwardian period and the most famous of the twentieth century, he was a restless yet thorough personality." (2004, p. 13). Shaw contributed to the humour scene with witty plays and critical ones such as Man and Superman, Pygmalion, Major Barbara and Arms and the Man.
Shaw's theatre is based on tackling controversial issues like social abuse, women's role in society, prostitution, hypocrisy and social / political change in general.

In the twentieth century, Alan Bennett represented one of the highly appreciated playwrights in the English contemporary theatre (BBC, 2017). Not only did he mark theatre, but also the British literary scene as a whole. Bennett is also a celebrated comedian, actor and screen writer. He achieved "instant fame with the influential satirical revue Beyond the Fringe" (Hall, 2006, p. 242). He provided theatre and the field of humour with a variety of wonderful plays, for which he has become a national treasure. He wrote The Madness of George the II, Forty Years On, The Lady in the Van, Single Spies, and he is "best known for his Talking Heads monologues, his TV adaptations and his hilarious memoires" (p. 242). His sarcastic work, which portrayed all sorts of characters, gained him an unprecedented success for decades.

In fact, theatres were not the only places that spread humour. Music halls formed other fertile venues that offered a different type of humour.

\subsubsection{Humour in music halls}

The music hall is a form of art and comedy that appeared in the nineteenth century due to increasing urbanization. Music halls witnessed an evolution from the London "pubs of the early nineteenth century to the grand music halls of the 1850s" (London Metropolitan Archives, 2010). Charles Dickens was known to frequent these music halls. The music hall was called a variety show because it gathered various performers: actors, singers, illusionists and comedians. Their shows attracted many spectators from different social classes. The music halls were a distinctive and a growing culture of English humour at that time (Faulk, 2004), and it kept on spreading until the invention of television and radio.

The music halls had various entertainment activities (singing, dancing, comedy ...), which were performed to entertain the public. They stood as the main populist events of the time, along with variety shows, where everybody could find fun and amusement in different acts done by numerous entertainers. "Thousands of artists used to travel the country performing ... in hall after hall" (Alexander, 1984, p. 64). Almost every town had its own hall. People frequented them to enjoy the latest dances, sketches, songs and jokes. Music halls reached their peak between 1890 and 1912 .

As written in Faulk (2004), the music halls were different from theatres. In music halls, spectators would sit at tables with alcohol while waiting for the spectacle to begin, but in theatres they sit in a tier. The audience in music halls was allowed to eat, drink and smoke during 
performances. The public would often go too far in heckling or singing with the artists.

As cited again in Faulk (2004), the growth of the music hall was rapid and the phenomenon was reincarnated throughout England. The music hall artists all became professionals. They played in several music halls and often toured the provinces. They performed songs that were written exclusively for them in a very humorous and sometimes dramatic manner.

In 1912, following Faulk (2004), the music hall gained a level of respectability. The London County Council banned food and drink definitively during the shows. From then on, the music halls were to be considered as theatres. The arrival of the cinema and radio put an end to the appearance of this kind of spectacles. The existing recordings of the music hall show that there were a lot of stars in the music hall production. Some of them were singers like Marie Lloyd, who was one of the adored stars and one of "the greatest music hall artists of her time in England," (Faulk, 2004, p. 24). Others were comedians like George Wild Galvin, famous for Dan Leno, Matilda Alice Powles, known as Vesta Tilley, Sir George Edward Wade, known as George Robey and George Formby, a renowned comedian in the 1940 s, who was widely famous for playing the banjo instrument that was the symbol of his fame.

\section{HUMOUR IN MOROCCAN CULTURE}

\subsection{Joking in Morocco}

Joking in Morocco is broadly popular. Whenever Moroccans meet in a friendly gathering or sit around the coffee table, jokes have a principal position in their conversations. Moroccans joke almost about anything, from small daily life routines to sophisticated and serious situations, and from ordinary people to high ranking personalities.

It is said that Moroccans do not laugh quickly. Although joking is very popular in Morocco, it seems that not any joke is likely to draw a wide smile on their faces. However, jokes that appear to satirize a dire reality or make fun of oneself, or those that look socially inapposite are said to cause real humour. This is because such jokes usually stem from repressed sentiments that, once released, can probably exhibit a great deal of humour (Eastman, 1921).

Indeed, most laughable situations are the ones that require the presence of others who come to receive a cheerful verbal or written speech or be part of it. Interestingly, the more familiar we are with the joke teller, the more laughs we experience, and the less we know the person, the less willing we are to engage in laughter. This is to say that we sometimes equate humour with, as asserted in Eastman (1921), a sense of security, harmony and acquaintanceship, and which can be described as unannounced conditions necessary for a comic situation to come off. Similarly, we constantly admire those who have a great sense of humour, and we usually seek to approach, befriend, or gather around the person who is famous for being witty and a successful joke teller.

Moroccans use jokes for diverse social functions. We frequently fall back on them in order to communicate with the others, to control certain behaviour through ridicule and to take away certain feelings, such as fear, as indicated in Martin (2007). Besides, we use humour to attack taboo issues, to transmit information, to promote social cohesion, to identify codes of palatable behaviour through criticism or ridicule and "to provide [oneself] with a sense of liberation or freedom from the constraints of life" (Martin, 2007, p. 48). These are, to a large extent, instances of popular culture; that is the culture of the common people who find in jokes "a way of forgetting the problems of life" (Sabri, 2005, p. 6), and a strategy to battle social inequality, to extend social bonds, to alleviate the scope of freedom of opinion, and so on and so forth.

In addition, the importance of humour in Morocco originates from the diversity of our society's environment with its different classes, tribes, regions and ethnicities. This richness includes "the Aroubi 'derogatory, peasant, uncultured'; the Shelh 'Berber', the Fessi 'Moroccan from the city of Fez' and the Mdini 'the modern who lives in the big city" (Sabri, 2005, p. 6). Jokes that typically reflect the local culture in the Sous region, for instance, and that are initiated there are likely to travel elsewhere, undergo some ingenious modifications and then end up being attached to another region or a person. Later, they become stereotypically glued to their new destinations sketching them as stupid, naive, mean, etc., such as the renowned story of "al-Joumani, an ex-member of the Moroccan government whose stupidity made him the symbol of idiocy in Moroccan popular culture" (Sabri, 2005, p. 6). This pours into the idea that humour focuses on issues of differences between individuals on a regional and tribal bases as well as the relationships between men and women, husbands and wives, teachers and students, locals and foreigners, the poor and the rich.

As a matter of fact, Moroccan jokes are said to mirror concealed emotions and thoughts that harbour feelings of joy and, sometimes, resentment. The power of jokes often lies in the purpose they reveal that often varies from a situation to another as in the case of some jokes that reflect people's social, cultural, political or economic 
circumstances as they are (Sabri, 2005). In a number of jokes, we usually issue a great deal of criticism towards reality that we think is hard to criticize formally. So, people often resort to implicit joking in order to disclose what lies beneath the surface of explicit formalities.

From another point of view, there is an implied relationship between humour and freedom of expression, at least in the Moroccan context. Jokes, ridicule, irony and satire flourish in the absence of freedom. The less free the society is, the more omnipresent humour (in the form of derision, satire, and so on) becomes, and it gets sharper once freedom further shrinks, taking the shape of what is called black humour.

The next section exhibits different aspects of humour traditions and practices in Moroccan culture in the past and present.

\subsubsection{Aspects of humour in Moroccan culture}

Humour represents a colossally significant constituent in Moroccan popular culture. Part of it is based on stories and story-telling, another is manifested through physical expression, while a third type mixes different acts in an atmosphere of passion and playful amusement. These comic expositions are seen as an opportunity to renew, foster or establish social ties and relationships between individuals or groups and between distant regions in the country. In this context, our culture is fraught with artistic and comic practices built around singing, acting, partying in masquerade, telling jokes, etc., such as Bu-jlud, alHalqa, al-Zajal ${ }^{1}$, humorous traditional banquets, elGharnati humorous songs, Ashura, sultan of students (Sultan Tulba) and other numerous aspects.

\subsubsection{Bu-jlud}

Every year after the Sacrifice Day ${ }^{2}$, Moroccans celebrate a humorous Halloween-like feast called Souna in Eastern Morocco and Bu-jlud (the man who wears skins), $B u$-ilmaun or Bu-btain in the rest of the country (Bakhti, 2013). A number of young people wear costumes made from goats' or sheep's woolen skins. They disguise in these masks and march through streets and neighbourhoods followed by kids and spectators to ask for charity, creating an atmosphere of joy, fun and humour. This is what Bu-jlud men used to do in the past. However, the tradition is no longer celebrated on a large scale as it was. Very few places still witness some practices of Bujlud celebrations, not in the traditionally popular way they were done, but just in the form of carnivals in main streets and venues.

Buj-lud, Bu-ilmaun, Bu-btain are all names of the same ritual that spreads in some southern parts of the country, like Taroudant. The celebration starts with a group of young men and women wearing artificial skins. They also put goats or sheep's horns over their heads in an attempt to look like the slaughtered animals on the Sacrifice Day (Aid el-Adha), which in turn makes the atmosphere incredibly hilarious. The disguised young men walk in different alleys dancing and playing drums, and accompanied by shouting children who particularly enjoy the whole ritual as most of us did when we were kids.

\subsubsection{El-Halqa (the circle)}

$\mathrm{El-Halqa} \mathrm{a}^{3}$ is one of the oldest forms of traditional theatrical humour in Morocco. It is a continuous living oral culture that has survived extinction, and is still practised to this day. For centuries, it has been played in open air by a variety of performers who keep no distance between them and the audience. The artists play different roles, do not usually put make-up and are not equipped with stunt material.

El-Halqa is presented in the form of prose / poetry, religious gatherings, stories of love, courage, betrayal and other

${ }^{1}$ Al-Zajal is part of the popular poetry that was, and still is, circulated in different Arab countries, including Morocco. It is a form of improvised traditional poetry that is performed in local dialects (Darija or Berber in Morocco).

${ }^{2}$ It is also called Aid el-kebir (Great Feast) or Aid el-Adha (Feast of the sacrifice). It commemorates Prophet Abraham's willingness to carry out God's commands and sacrifice his son. It comes two lunar months and ten days after Aid es-Sghir, which is the celebration that marks the end of the fasting month [of Ramadan] (M. Bakhti, 2013).

${ }^{3} \mathrm{El}$-Halqa is a "public gathering in the form of a circle around a person or a number of people (hlayqi/hlayqia) in a public space (be it a marketplace, a medina gate, or a newly devised downtown square). It is a space of popular culture that is open to all people from different walks of life" (Amine, 2001, p. 55).

social issues, as well as politics, morality, death, etc. It starts with a small introduction that praises God, which is addressed either in Arabic, in Moroccan Darija or in a local Amazigh dialect. The performer always relies on his movements, gestures, facial expressions, the tone of his voice and his comedy skills to attract people and create laughter.

Historically, el-Halqa started with a man travelling through markets, rural souks, villages and cities, and was usually seen in public squares, particularly in Jama'a Lafna, Marrakech (Amine, 2001; Boukous, 2004). The hlayqi (the person making el-Halqa) kept telling stories about prophets and their miracles, inventing tales about historical figures or exotic countries, often with great exaggerations, transmitting news of previously visited 
areas, etc. Such a marvellous show takes the spectators into aworld of humour, magic, adventure, evil and joy.

Nowadays, el-Halqa is directly related to Jama'a Lafna, the famous square in Marrakech. It is almost the only place where many shows are still present, and where one can see live performances of dancers, music bands, acrobats, snake charmers, joke tellers, sorcerers and fortune tellers. In the 1960s and 1970s, the cities of Beni Mellal, Meknes (Lahdim Square) and Fez (Bu-jlud Square) were also renowned locations that held similar shows in the past.

Over time, el-Halqa became an organized profession with rights and duties. The rationale that pushed for this move was to preserve Moroccans' collective memory, promote national heritage and resuscitate folk culture. Most of our folk tales and legends have been transmitted to us through oral culture and with the help of our grandmothers who often have ample stories to tell to their grandchildren. In fact, this is what el-Halqa performers do when they take their spectators on a journey of wonder and amazement.

\subsubsection{Ashura}

Ashura constitutes another ritual wherein Moroccans revive a tradition that is plenty of amusement. Even if it is a sad event in some eastern countries that commemorates the killing of the prophet's grandson Hussein Ibn Ali, it is a religious occasion observed in Morocco by fasting, charity and joy in commemoration of the saviour of Moses.

Moroccans celebrate Ashura, also called the $10^{\text {th }}$ of Muharram, not only by fasting and charity, but also by other rituals. Families prepare special Moroccan meals and dishes like Rfisa and Couscous. They buy several types of dry fruits that they eat from time to time during the anniversary days. Besides, they buy a collection of toys for children, who turn to be the main beneficiaries of Ashura, like dolls, cars, water sprayers and so many others.

Additionally, a lot of children and youngsters seize the Ashura occasion to engage in a variety of games. Children meet in popular alleys and neighbourhoods to gather woods, set fire to them, then hover around and jump. Fire crackers with all the noise they make are also an essential part of the fire games that coincide with singing and playing the hand-size drums (t'aryja). At the peak of the celebrations, children and teens spend the day playing with water, often splashing their peers and other pedestrians from balconies and windows in an undesirably ridiculous but funny manner. This is a custom that has come to be known as Zamzam, a word that refers to Zamzam ${ }^{4}$ water in Mecca.

\subsubsection{Sultan of students}

This was a celebration that used to be held in fez and Marrakesh during and before the French protectorate, where one of the students from the Qarawiyyin University in Fez or Usufiya-Mosque Univeresity ${ }^{5}$ in Marrakesh plays the role of the sultan in a big crowded feast (Eickelman, 1985; Chaqir, 2014; S idi, 2006).

Celebrating this ritual would take a whole week of fun and humour. It was a highly social and cultural event since it was part of people's way of life, and most importantly because it was a remarkable moment of entertainment for everybody. The festivity starts with inaugurating one of the students, usually the most diligent one, to be a mock sultan for a period of three weeks. The student named sultan appoints his government and his entourage from fellow students. The celebration takes to the streets where the student-sultan is surrounded by a convoy that enjoys the same prestige as that of the country's real sultan. On this occasion, the student-sultan can put forward some demands to the real sultan that concern the students and the

\footnotetext{
${ }^{4}$ Muslims believe that it is a miraculous well that has been generating water since Abraham's time. It is located next to alMasjid al- Haram (the Holy Mosque) in Mecca.

5 Al-Qarawyyin University is one of the world's oldest existing and continuous universities. It was founded in Fez by Fatima alFihriya in the 9th century. Usufiya-Mosque University was like the Qarawyyin. It was located in Marrakech, and was founded in the 16th century (Eickelman, 1985).
}

country. Here is how Eickelman (1985) described this carnival:

It was an annual occasion on which the sultan and his entourage publically acknowledged students as a collectivity. Each spring, students solicited contributions from townsmen, and a student was proclaimed sultan for the duration of a three-week outing (nuzha). The real sultan's parasol, a symbol of authority, was often loaned to the student sultan for the duration. The student sultan appointed his peers to offices in his entourage, mirroring the real Makhzan. The first week of festivities included a major Friday procession. The next day, the real sultan's ministers visited their student counterparts with gifts. Sunday was the turn of the real sultan, before whom a burlesque Friday sermon 
(khutba) was delivered. ... At the end of the sermon, the real sultan gives his student counterpart cash and gifts so that the students can prolong their festivities (p. 88).

Admittedly, all these rituals constitute a widespread practice of Moroccan popular culture as they are closely connected to the history of our social customs and peoples' life style. These rituals and other comic events usually revolve around playfulness, which is always associated with humour. Moreover, what is intriguing and fascinating is that Moroccans believe in an implied relationship between humour and danger or bad omen. Therefore, they often finish a joke or an act of humour by saying 'may God end this laughter well' (Allh yharrej had dahk 'ala hir). It is an unconsciously inherent verbal behaviour that is fearful of the consequences of laughter.

\section{CONCLUSION}

There is an intertwined relationship between culture and humour. Each pours into the other. Appreciating humour requires an understanding of its culture; this is why it is important to look through the various cultural and societal aspects that are characteristic of Morocco and England, as they are two of the world's oldest continually serving monarchies.

\section{REFERENCES}

[1] Alexander, R. (1984). British comedy and humour: Social and cultural background. AAA: Arbeiten aus Anglistik und Amerikanistik, 9(1), 63-83. Retrieved from http//www.jstor.org/stable/43023313

[2] Amine, K. (2001). Crossing borders: Al-halqa performance in Morocco from the open space to the theatre building. TDR, 45(2), 55-69.

[3] Bachleda, k., Fakhar, A., Slimani, S., \& Elgarah, W. (2014). The outdoor leisure behaviour of Moroccan public sector workers. Leisure/Loisir, 53-72. Retrieved from https://www.researchgate.net/publication/269405967_The_o utdoor_leisure_behaviour_of_Moroccan_public_sector_wor kers

[4] Bakhti, M. (2013). Culture: Legacy versus modernity. In A. Sellam, \& M. Dellal (Eds.), Moroccan culture in the 21st century: Globalization, challenges and prospects. New York: Nova Publishers.

[5] BBC. (2017, August 19). Being Alan Bennett. Retrieved from www.bbc.co.uk: http://www. bbc. co.uk/programmes/b00pcbtj

[6] Bennett, M. J. (1993). How not to be a fluent fool: Understanding the cultural dimension of language. Retrieved from https://www.google.com/url?sa=t\&rct=j\&q=\&esrc=s\&sourc $\mathrm{e}=$ web $\& \mathrm{~cd}=2 \& \mathrm{cad}=\mathrm{rja} \& u a c t=8 \& v e d=0$ ahUKEwilx_eq0q3
YAhUGRhQKHULvDsgQFggrMAE\&url=http $\% 3 \mathrm{~A} \% 2 \mathrm{~F} \% 2$ Fdigitalcollections.sit.edu $\% 2 \mathrm{Fcgi} \% 2 \mathrm{Fviewcontent.cgi} \% 3 \mathrm{Ffi}$ lename\%3D10\%26article\%3D1001\%26context\%3Dworldle arning_publ

[7] Bloom, H. (2004). Elizabethan drama. New York: InfoBase Publishing.

[8] Bloxham, A. (2008, March). British humour 'dictated by genetics'. Retrieved from http://www.

[9] telegraph.co.uk/news/uknews/1581251/British-humourdictated-by-genetics.html

[10] Chakir, A. (2003). Alfukaha wa dahik : Roaya jadida [humour and laughter: A new vision]. Kuwait: 'Alam alMa'arifa.

[11] Chaqir, M. (2014). Alqadasa wa hadru assuhrrya bi almaghrib [Holiness and the prohibition of sarcasm in Morocco]. In Abhat fi alfukaha wa suhrya: Alwarcha alhamisa (pp. 135-143). Rabat: Abi Raqraq.

[12] Davies, A., \& Sinfield, A. (2000). British culture of the postwar: An introduction to literature and society 19451999. London: Routledge.

[13] Eastman, M. (1921). The sense of humour. New York: Charles Scribner's Sons.

[14] Edgar, A., \& Sedgwick, P. (2008). Cultural theory: The key concepts . London: Routledge.

[15] Eickelman, D. E. (1985). Knowledge and power in Morocco: The education of a twentieth-century notable. Princeton: Princeton University press.

[16] Elinson, A. (2009). Opening the circle: Storyteller and audience in Moroccan prison literature. Middle Eastern Literatures, 02(3), 289-303.

[17] Faulk, B. J. (2004). Music hall \& modernity: The lateVictorian discovery of popular culture. Athens: Ohio University Press.

[18] Featherstone, M. (1990). Global culture: Nationalism, globalization and modernity: A theory, culture \& society . London: Sage.

[19] Fox, K. (2004). Watching the English: The hidden rules of English behaviour. London: Hodder \& Stoughton.

[20] Gerrard, S. (2013). The great British music hall: Its importance to British culture and 'the trivial'. $C U$ Culture Unbound: Journal of Current Cultural Research, 5(4), 487513. Retrieved from http://www.cultureunbound.ep.liu.se/v5/a29/cu13v5a29.pdf.

[21] Gert, J. H. (n.d.). Humour across cultures: An appetizer. Retrieved

from https://www.semanticscholar.org/paper/Humour-acrosscultures-\%3A-an-appetizerHofstede/4f2fddee 5330 cf8ac76a9171dafb30f b0388c4cf

[22] Hall, J. (2006). The rough guide to British cult comedy. London: Rough Guides .

[23] Helmke, M. (2007). Humor and Moroccan culture. Matthew helmke.

[24] Humphrys, D. (2008). Frommer's Morocco. New Jersey: Wiley Publishing.

[25] Inglis, D. (2005). Culture and everyday life. New York: Routledge. 
[26] Jiang, T., Li, H., \& Hou, Y. (2019). Cultural differences in humor perception, usage, and implications. Frontiers in Psychology, 10.

[27] Jonathan. (2010, August 13). Guest post: A quick guide to British humor - understanding British comedy. Retrieved from http://www.anglotopia.net/britishidentity/humor/guest-post-a-quick- guide-to-british- humorunderstanding-british-comedy/

[28] Kershaw, B. (2004). The Cambridge history of British theatre (Vol. 3). Cambridge: Cambridge.

[29] Lee, R. (2006). Globalization, language, and culture. Philadelphia: Chelsea House.

[30] Lewis, R. D. (2006). When cultures collide: Leading across cultures. London: Nicholas Brealey.

[31] London Metropolitan Archives. (2010, Mach 2). Sources for the history of London theatres and music halls at London Metropolitan Archives [Brochure]. Retrieved from https://www. cityof

[32] london.gov.uk/things-to-do/london-metropolitanarchives/visitor- information/ Documents/47-theatre-andmusic-hall-sources-at-lma.pdf

[33] Lu, G. J., Martin, A., Usova, A., \& Galinsky, D. A. (2019). Creativity and humor across cultures: Where Aha meets Haha. 1-33.

[34] Lublin, R. I. (2011). Costuming the Shakespearean stage: Visual codes of representation in early modern theatre and culture (studies in performance and early modern drama). Ashgate Publishing Group.

[35] Martin, R. (2007). The psychology of humor: An integrative approach. Burlington.

[36] Marx, E. (1999). Breaking through culture shock: What you need to succeed in international business. London: Nicholas Brealey Publishing Ltd.

[37] Michalik, U., \& Sznicer, I. (2017). The use of humour in the multicultural environment. Springer International Publishing, 19-32.

[38] Miling, J., \& Thomson, P. (2004). The cambridge history of British theatre (Vol. 1). Cambridge: Cambridge University Press.

[39] Mubeen, H. (2008). Humour and comedy in Arabic literature: From the birth of Islam to Ottoman period. $\mathrm{Al}$ Hikmat, 28, 13-30.

[40] Muller, A. (2005). Concepts of culture: Art, politics, and society. Calgary, Alberta: University of Calgary Press.

[41] Njoku, C. R. (2006). Culture and customs of Morocco. London: Greenwood Press.

[42] Opinium Research. (2017). Multicultural Britain in the 21st century: What people think, feel and do. Opinium Research. Retrieved from https://www.opinium.com/wpcontent/uploads/2017/07/Multicultural-Britain-2017-v6.pdf

[43] Orlando, K. V. (2011). Screening Morocco: Contemporary film in a changing society. Athens: Ohio University Press.

[44] Rose, J. (2010). The intercultural life of the British working classes. New Haven: Yale University Press.

[45] Ross, A. (1998). The language of humour. London: Routledge.

[46] Sabri, T. (2005). Migration as popular culture. Retrieved from http://www.portalcomunicacion. com/bcn2002/n_eng/programme/prog_ind/papers/s/pdf/s007 _sabry.pdf

[47] S'idi, E. B. (2006). Min adab alfukaha bi almaghrib: Hotab alwala'em alhazlya [From the literature of humour in Morocco: Sermons of comic banquets]. In Madarat Taqafia wa Fikria (1st ed.). Fez, Morocco: Info Print.

[48] Tebbe, T. (2008). The funny side of the United Kingdom: Analysing British humour with special regard to John Cleese and his work, Seminar presented at the University of Osnabruck. Munchen, 2008: Grin Verlag. 